\title{
İç Mekânda Kullanıcı ve Doğal Çevre Etkileşiminin Mental İyi Oluş Durumu Üzerindeki Etkisinin Mimar Sinan Güzel Sanatlar Üniversitesi Örneğinde Ölçülmesi
}

Arş. Gör. Hatice Aşkın

Makale Geliș Tarihi: 09.06.2020

Prof. Dr. Burçin Cem Arabacıoğlu

\section{Özet}

Korunma ve barınma amacılla yapma çevre oluşturmaya başlayan insan, bu eylem ile yaşam alanlarııı tahrip ederken, doğal çevre ile arasındaki etkileşimi de kısıtlamıştır. Özellikle şehirlerde doğal çevreden kopmuş olmak bir problem haline gelmiştir.Insanlar beton bloklar içinde, doğal çevreyi hayatlarına dâhil edemeden yaşamaktadır. iç mekânlarda geçirilen süre dikkate alındığında bu etkileşimi iç mekânlarda kurabiliyor olmak son derece önemlidir. "iç mekânda doğal çevre ile etkileşim kurmak kullanıcıların mentâl iyi oluş durumunu olumlu yönde etkiler" hipotezi ile bu çalışmada; doğal çevre-insan-mekân etkileşimleri, doğaya yönelme fikrinin sebepleri ve bu etkileşimin neden sağlanması gerektiği irdelenmiştir. Hipotezi test etmek üzere öğrencilerden oluşan bir deney grubu oluşturulmuştur. Bu deney kurgusunda üç aşamalı olarak; doğal çevre unsurları ile etkileşimi olan yapma çevre unsurları ile etkileşimi olan ve hem doğal çevre hem de yapma çevre unsurları ile etkileşimi olan sinıflarda çalışmalar gerçekleştirilmiştir. Çalışmaların sonunda katılımcılar tarafindan Mentâl lyi Oluş Ölçeği cevaplandirılmıștır. Elde edilen veriler hipotezi destekler niteliktedi.

Anahtar Sözcükler: Doğal Çevre, Yapma Çevre, iç Mekân, Mentâl liyi Oluş.

EVALUATION OF THE EFFECT OF INTERACTION BETWEEN THE USER AND THE NATURAL ENVIRONMENT IN THE INTERIOR SPACES ON MENTAL WELL-BEING IN THE EXAMPLE OF MIMAR SINAN FINE ARTS UNIVERSITY

\section{Abstract}

Human beings who started to create artificial environment for protection and shelter, restricted their interaction with the natural environment while destroying their habitats with this action. Especially in cities, being disconnected from the natural environment has become a problem. People live in concrete blocks and cannot incorporate the natural environment into their lives. Taking into account the time spent indoors, it is extremely important to be able to establish this interaction indoors. In this study, with the hypothesis that" Interacting with the natural environment in the interior positively affects the mental well-being of the users", the natural environment-human-space interactions, the reasons for the idea of turning to nature and why this interaction should be provided were examined. An experimental group which have consisting of university students was should be provided were examined. An experimental group which have consisting of university students was being. This experiment wasts of interaction with the natural environment in the interior on the mental wellbeing. This experiment was conducted with the same participants in three stages with different settings; in classrooms that have interaction with the natural environment, that have interaction with artificial environment, the Mental Well-Being Scale was answered by the participants, and the data received supporting the hypothesis.

Keywords: Natural Environment, Artificial Environment, Interior Spaces, Mental Well Being. 


\section{Giriş}

Birçok canlı doğal çevre ile uyumlu bir şekilde hayatını sürdürürken doğanın bir parçası olan insan, korunma ve barınma amacıyla yapma çevre oluşturmaya başlamışırı. Tarımla birlikte gelen sürekli ikamet durumu, barınma amacıyla başlayan bu yapma çevrenin zamanla köylere, kasabalara ve kentlere dönüşmesine neden olmuştur. Yapma çevre oluşturma süreci endüstrileşme ile birlikte doğal çevrede tahribatlara sebep olmanın yanı sıra insan ve doğal çevre arasındaki etkileşimi de kısıtlamışıı. Yaşam alanlarında erişilebilecek doğal çevre unsurlarının azalması insanlarda doğal çevre ile etkileşim kurma ihtiyacının artmasına neden olmuştur.

Yıllardır doğaya hükmetmeye çalışan insan, verdiği tahribattan sonra yarattığı yapma çevreden rahatsız olmaya başlamıştır. Doğal çevre ile bir harmoni içerisinde yaşaması gerektiği gerçeğini kavramıştır. Özellikle büyük şehirlerde doğal çevreden kopmuş olmak yaygın bir problem haline gelmiştir. Ancak insanlar beton bloklar içinde yaşamaya devam etmekte ve doğal çevreyi hayatlarına dâhil edememektedirler. Bu eksiklik giderek dikkat çekerken kullanııılar günlük hayatlarında doğal çevre ile buluşabilecek seçimler yapmaktadır. Konutların güneșin yönüne göre seçilmesi, bulunduğu konuma dikkat edilmesi; deniz kenarına yakın veya en azından deniz gören evlerin daha çok talep görmesi, yeşil alanlara yakın ev-iş yerlerinin tercih nedeni olması, iç mekânlarda canlı bitki kullanımı gibi birçok seçim bu arayışın göstergesi niteliğindedir. Fakat bu imkânlara ulaşmak herkes için mümkün değildir. Maddi koşulların yetersizliğinin ötesinde kentler doğal çevre unsurları bakımından oldukça fakirdir ve kontrolsüz şehirleşme ile birlikte gitgide fakirleşmektedir.

Elde edilen veriler ise yaşam alanlarında doğal çevre ile etkileşim kurmanın zorlaşacağını göstermektedir. İnsan tarihinde ilk defa dünya nüfusunun çoğunluğu şehirlerde yașamaktadır. 2030 yilına kadar her 10 kişiden altısııın, 2050 yılına kadar ise her 10 kişiden yedisinin kentlerde yaşaması beklenmektedir ${ }^{1}$.Mimarlık, peyzaj mimarlı̆̆ı, sağlık gibi çeşitli disiplinlerde, doğal çevre ile etkileşim halinde olmanın insanın psikolojik ve fizyolojik sağlığına önemli katkılar sağladığını gösteren araştırmalar mevcuttur. İç mekânlarda geçirilen zaman ve kentsel nüfusun gittikçe artıyor oluşu göz önüne alındığında iç mekânlarda doğal çevre unsurları ile etkileşimi geliştirmek özellikle iç mimarlık alanı için oldukça önemli hale gelmiştir. iç mekânlarda geçen sürenin azalma intimali görülmemektedir. Ayrıca Covid-19 salgınının ardından bu sürenin kaçınılmaz bir biçimde artacağı beklenmektedir.

' https://www.who.int/health-topics/urban-health/urban-health-gallery (Erișim Tarihi 06.06.2020)
Hem psikolojik hem de fizyolojik sağlığımız için doğal çevre ile etkileşimi güçlendirmemiz gerekmektedir. Hava-oksijen nasıl yaşamımız için zorunlu ise doğanın diğer parçaları da psikolojik ve fizyolojik olarak sağlıklı bir şekilde hayatımızı sürdürmemiz için gereklidir.

“íç mekânda doğal çevre unsurları ile etkileşim halinde olmak kullanıcıların mentâl iyi oluş durumlarını olumlu yönde etkiler" bu çalışmanın hipotezini oluşturmaktadır. Çalışmanın amacı doğal çevre unsurlarını yaşamımızın büyük bir çoğunluğunu geçirdiğimiz iç mekânlara dâhil etmenin önemine dikkat çekerek, doğal çevre-iç mekân-kullanıc etkileşimini sağlamanın yollarını geliştirmektir. İç mekanda doğal çevre unsurları ile etkileşim kurmanın iç mimarlık alanı için dikkate alınması gereken bir unsur olduğunu vurgulamak çalışmanın hedeflerinden biridir. Bu çalışmanın ele aldığı konuların uygulamaya geçmesiyle birlikte insan-doğal çevre etkileşiminin sağlanarak toplumun yaşam kalitesinin artması, konunun önemi vurgulanarak insanların bilinçlenmesi ve mekân üretim sürecine dâhil olan bütün disiplinlerin faydasına olabilecek bir çalışma oluşturulması amaçlanmaktadır.

Bu çalışmada doğal çevrenin birey üzerindeki psikolojik etkisi iç mimarlık kapsamında ele alınmaktadır. Iç mekânda doğal çevre unsurları ile etkileşimin psikolojik etkisini ölçmek için bir deney kurgusu oluşturulmuştur. Bu deney kurgusunda aynı katılımcılar tarafından üç aşamalı olarak; doğal çevre ile etkileşimi olan, sadece yapma çevre ile etkileşimi olan ve son olarak da hem doğal çevre hem de yapma çevre ile etkileşimi olan sınıflarda çalıșmalar gerçekleștirilmiștir. Bu çalıșmaların sonunda birçok alanda kullanılan nitel araştırma yöntemlerine dâhil olan veri toplama araçlarından mentâl iyi oluş ölçeği deney grubu tarafından cevaplandırılmıştır. Bu ölçek 14 sorudan oluşmakta ve bireyin psikolojik iyi olus durumunu ölçmektedir. Mentâl iyi oluş ölçeği kullanılırken çalışıan grup ise bazı şartlar göz önüne alınarak seçilmiştir. Öğrencilerin aktif olarak çalıştığı, teori anlatımından ziyade uygulamanın ön planda olduğu iç mimarlık bölümünden öğrenciler seçilmiş ve bölüm içeriğine uygun çalışma grubu oluşturulmuştur. Ayrıca bu grup seçilirken dikkat edilen diğer husus ise öğrencilerin birinci sınıf olmasıdır. Çünkü çalışmalarında dikkat unsurunun önemli bir etken olduğu iç mimarlık gibi uygulamalı bir alanda bir takım yöntem ve tekniklerin yeni kazanıldığı, birinci sınıf grubunda, bulundukları sınıfın doğal çevre unsurlarına sahip olup olmamasının daha hissedilebilir fark yaratacağı düşünülmüştür.

\section{Doğal Çevre, İnsan ve Mekân Tasarımı}

Doğal çevre, insan ve mekân arasındaki ilişkileri açıklamak adına öncelikle çevre kavramı irdelenmelidir. Anlam bakımından oldukça geniş bir 
yelpazeye sahip olan çevre, kolay açıklanabilir gibi görünse de çok çeşitli tanımlamalara sahiptir. Örneğin; ekologlar çevreyi dünyanın canlı varlıkları ile bu varlıkların yaşadığı ortamdaki hava, su, toprak ve doğal kaynaklardan oluşmuş bir sistem olarak açıklarken; toplumbilimciler bir bireyin, bir toplumsal kümenin ya da toplumun biyolojik, toplumsal ve kültürel yaşamını etkileyecek dış şartların bütünüdür, şeklinde açıklamaktadır (Taşkın, 2010: 242). "Ben olmayan her şey çevredir." cümlesiyle Einstein bu çeşitliliğin kapsamını göstermektedir (Turgut, 2001: 73). Bu tanımlamaların ilgilenilen alana göre çeşitlenmekte olduğu görülmektedir. Bu çalışmada ise öncelikle fiziksel çevre başlığı altında doğal ve yapma çevre, devamında ise sosyal çevre olmak üzere incelenmektedir. İnsanın içinde yaşadığı, varlığını, özelliğini ve niteliğini fiziksel olarak algıladığı ortam olan fiziksel çevre; oluşumu bakımından doğal ve yapma çevre olmak üzere ikiye ayrılmaktadır (Keleş ve Hamamcı, 2005: 34). Canlı ve cansız olmak üzere iki bileşeni olan doğal çevre, oluşumunda insanın katkısının olmadığı, hazır bulduğu bir çevredir. Doğal çevrenin canlı öğelerini insan, bitki, hayvanlar ve mikroorganizmalar oluştururken cansız öğelerini hava, su, toprak, yer kabuğunu oluşturan katmanlar ve yer altı kaynakları oluşturmaktadır. Insanın doğal çevresinde bulmuş olduğu yer altı ve yer üstü kaynaklarını kullanarak yarattığı çevre ise yapma çevreyi oluşturmaktadır. Yapma çevrenin temel özelliği insan elinden çıkmış olmasıdır (Karataş, 2013: 82).

Doğal ve yapma çevre insanın fiziki çevresini oluştururken, insanın ekonomik, toplumsal ve siyasal ilişkilerinin tümünü içinde barındıran sosyal çevre ise kültürel çevresini oluşturmaktadır. Bu bakımdan sosyal ve fiziksel çevre birbirini tamamlamaktadır (Tıraş, 2012: 65). Sanayi, turizm, ulașım, tarım, madencilik gibi faaliyetlerden soyutlanmış bir fiziksel çevre düşünülemediği gibi, orman, nehir, mera, deniz, çöl, toprak gibi çeşitlendirebileceğimiz doğal çevre unsurlarından etkilenmeyen bir sosyal çevre de düşünülemez. Bu nedenle sosyal ve fiziksel çevre karşılıklı etkileşim içinde bulunan değişken ve çok boyutlu bir bütünün parçalarını oluşturmaktadır (Atasoy, 2015: 41).

\subsection{Doğal Çevre ve İnsan}

Doğal çevre ve insan arasındaki etkileşimi güçlendirmenin nedenlerini anlamak için öncelikle insan ve çevre arasındaki etkileşiminin tarihini irdelemek gerekmektedir. Doğal çevrenin bir parçası olan insan, iki milyon yıllık varoluşunun ilkel döneminde yiyecek toplayarak ve avlanarak yaşamını sürdürmüştür.Göçebe olarak yaşanan ilkel dönemde doğada hazır bulunan ağaç kovukları ve mağaralar, barınma ve korunma gibi temel ihtiyaçların karşılandığı ilk mekânlar olarak karşımıza çıkmaktadır (Roth, 2014: 202).
Ayrıca insanlar kaynakların işlendiği bölgelerde dallardan yapılmış, temelinde toprak yığınları bulunan, üstü bitkilerle örtülü yapma çevrenin ilk modelleri olan geçici barınaklar kurmuşlardır (Monnier, 2013: 10). Bu barınaklar yaşama çevresinin bilinçli şekillendirilmesine doğru atılan ilk adımlar olarak bilinmektedir (Roth, 2014: 204).

Ateşin kullanılmaya başlamasından sonra doğal çevre ve insan etkileşiminde MÖ 9500-8500 yılları arasında başlayan tarım önemli bir yere sahiptir. Tarım göçebe olarak yaşayan insanları toprağa bağlayarak kalıcı yerleşim alanları benimsemesini sağlamıştır (Roth, 2014: 210). Tarımla birlikte başlayan sürekli ikamet durumu zaman içinde barınakların köylere, kasabalara ve kentlere dönüşmesine neden olmuştur.

Tarım devrimi tarihteki en tartışmalı konulardan biri olarak görülmektedir. Insanlığın gelişim ve refah yolunda attığı büyük bir adım olarak değerlendirilen tarım devrimi, Jared Diamond gibi bazı araştırmacılar tarafından ise insanın doğa ile uyumlu yaşamını bırakıp açgözlülük ve yabancılaşmaya doğru bir koşuşu olarak değerlendirilmektedir. Eski avcı toplayıcıların yaşam alanları tepeler, dereler, ağaçlar ve gökyüzüyle beraber kilometrekarelik çeşitli alanları kapsamakta iken tarım hayatına geçiş yapmış olan köylülerin yaşam alanları tarlaları, meyve bahçeleri ve taş, çamur, ahşap gibi çeşitli malzemeler ile yapmış oldukları barınakları kapsamaktadır. Köy hayatı yaşayan ortalama bir insan evine çok ciddi bir bağlılık geliştirmiştir ve bu durum mimari olduğu kadar psikolojik yönleri de olan, etkileri oldukça geniş bir devrimdir (Harari, 2015: 108). Buğdayı evcilleştirdik olarak aktarılırken aslında buğdayın bizi evcilleştirmiş olduğunu ifade etmekte olan Harari'ye göre Tarım Devrimi yeni ve kolay bir yaşam biçimi sağlamaktan ziyade nüfus patlamasına yol açan dünyanın en büyük aldatmacasıdır. Tarım devriminin özü de Homo Sapiens'in katlanarak çoğalmasını sağlamasıdır (Şekil 1.).

Tarım ile birlikte yerleşik düzene geçilmesinden sonra Sanayi Devrimine kadar insanların mekân tasarım eylemlerinde doğal çevreye olan müdahaleleri oldukça ölçülü olmuştur. 18.yüzyılda Sanayi Devrimi ile enerjiyi dönüştürmek ve yeni ürünler geliştirmek için yeni yollar yaratan insan, etrafını çeviren ekosisteme bağlı kalmaktan da büyük ölçüde kurtulmuștur. Insanlar bu gelişmelerle birlikte ormanları kesmiş, bataklıkları kurutmuş, barajlar yapmış, ovaları sulamış, binlerce kilometre demiryolu döşemiş ve gökdelenlerle dolu metropoller kurmuştur. Bunların neticesinde ise çeşitli habitatlar ve türler dünya insanların istekleri doğrultusunda değiştirildikçe yok olmuştur. Yeşil ve mavinin hâkim olduğu doğal çevrenin yerini plastik ve betondan oluşan bir orman almıştır. (Harari, 2015: 345). 

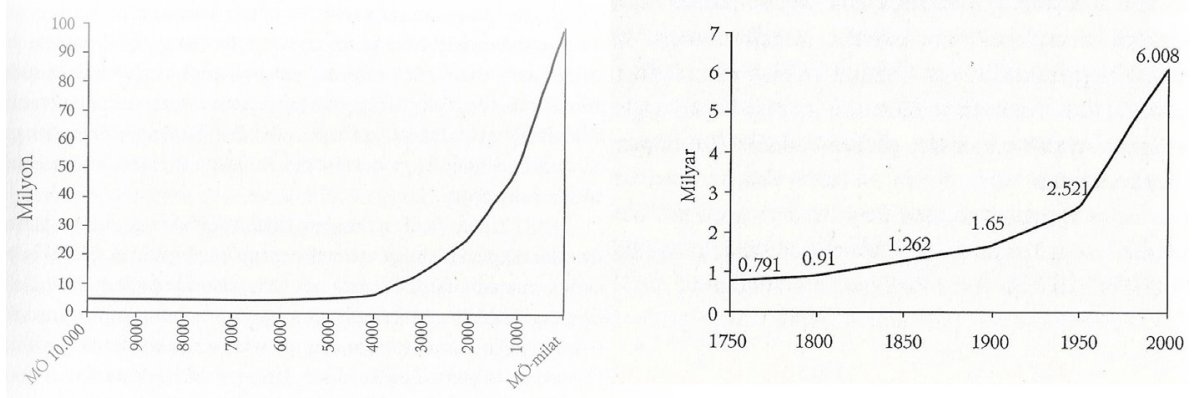

Şekil I. Dünya Nüfusu, MÖ. 10.000- Milat ve 1750-2000 (Ponting, 20I2:47-280).

Tarım ile başlayan nüfus artışı Sanayi Devrimi ile birlikte hiç görülmeyen oranda artmaya başlamıştır (Şekil 1.). Geçmiş yıllardan günümüze kadarki nüfus artışı aynı hızla devam ederse 2050 yılına gelindiğinde dünya nüfusunun 9 milyarı geçeceği tahmin edilmektedir (Hun, 2016: 50).

Sanayileşme ile birlikte artan nüfusun makineleşmeden dolayı işsiz kalmasıyla birlikte kentlere göç etmesi hızlı bir kentleşme sürecini de başlatmıştır (Atasoy, 2015: 32). Son iki yüzyıl içinde kentlerin ve kentsel yaşamın yükselişiyle birlikte, insanların yaşam biçiminde ve çevredeki en büyük değişimlerden biri yaşanmıştır ve kentler, insanların oluşturmuş olduğu en büyük yapma çevreler haline gelmiştir (Ponting, 2012: 357). Zamanla gelişen ve büyüyen kentler, günümüzde tarihinin en büyük dönüşüm noktasını yaşamaktadır. Hiçbir tarihte kent nüfusu günümüzde olduğu kadar çok olmamıştır. 1800 yılında yaklassı 27 milyon insan kentlerde yaşamaktayken bu rakam 1900 yılında on kat artarak 225 milyona çıkmıştır. 1950'de ise dört kat artışla 810 milyona yükselmiş, sonraki elli yıl içinde üç katı aşan bir artış görülmüş ve kentlerde yaşayan nüfus 2,9 milyar kişiye ulaşmışıtır. Toplamda ise son iki yüzyıl içinde, kentlerde yaşayan insan sayısı 107 kat artmıştır (Ponting, 2012: 357).

Insanın yavaş yavaş gelişen yapılaşma eylemi zamanla nüfus artışıla birlikte o kadar hızlanmıştır ki doğal çevrede tahribatlara sebep olmanın yanı sıra insan-doğal çevre arasındaki etkileşimi de kısıtlamıştır. Sanayi Devrimi ile birlikte kentleşmenin de hızla artması, insan ve doğal çevre arasında kısıtlanan etkileşimi ve doğal çevredeki zararı maksimum düzeye çıkarmıştır. İnsanların yaşam alanlarında erişilebilecekleri doğal çevre unsurunun azalması zamanla doğal çevre ile etkileşim kurma intiyacının fark edilmeye başlanmasına ve bu ihtiyacın giderek artmasına neden olmuştur. 21.yy.'a gelindiğinde bu problemlere çözüm arayışı içerisine giren insan yeniden doğaya yönelmeye başlamıştır. Bu ihtiyaçlar neticesinde mekân tasarımında korunak teşkil etme ve uygun iç mekân koşulları sağlamanın yanı sıra, doğal çevre unsurlarını tahrip etmeden çevreye duyarlı ve uyumlu yapılar inşa etmek başıca amaçlardan biri haline gelmiştir.

\section{3. İç Mekânda Doğal Çevre İle Etkileşimin Kullanıcılar Üstündeki}

\section{Etkileri}

Doğal çevre, insan ve mekân tasarımı ilişkisi insanın yaratmış olduğu yapma çevre ile parçası olduğu doğal çevreden kopmasıyla sonuçlanmıştır. Hayatının çoğunluğunu iç mekânlarda geçiren insan doğal çevreye ulaşamamakta ve beton bloklar içinde yaşamaktadır. Doğal çevreye olan ihtiyacın hissedilmeye başlandığı açıktır ve bu durumun yansımaları birçok yerde karşımıza çıkmaktadır. Örneğin; doğaya yakın bir çevreye sahip olma arzusu şehirlerden uzak bölgelere taşınma isteğini körüklemiştir. İronik olarak doğa içinde kurulan bölgelerin ortaya çıkmasıyla doğada gerçekleştirilen yıkıma bir yenisi daha eklemiştir (McNally, 2014: 13). Benzer oluşumlara birçok yerde rastlanmaktadır ve doğal çevreye ulaşmaya çalışan insan yarattığı yapma çevre ile doğal çevreye zarar vermeye devam etmektedir.

Doğal çevre ve insan arasındaki ilişki ile ilgili çağdaş toplumda insanların başarılarının, doğayı kontrol etmeye ve dönüştürmeye bağlı olduğuna dair olan yaygın inanç varken, bir yanda da insanın fiziksel, zihinsel ve ruhsal esenliğinin, sağlıklı ve çeşitli doğal çevre unsurunu deneyimlemeye dayandığı inancı vardır. İnsanın hayatını sürdürmesi için yapma çevre oluşturması kaçınılmazdır ancak bu oluşum sürecinde öncelikle doğal çevreye zarar vermeyen ve ona ulaşımı engellemeyen yöntemler geliştirerek kullanmalıdır.Amerika'da yapılan araştırmalar, yeşil alanlara yakın evlerin daha pahalı olduğunu, bu evlerin daha az el değiştirdiğini ve doğal çevre unsurlarına sahip olmayan yerlerde yaşayan insanların yaşadıkları çevreden hoşlanmadıklarını göstermektedir. Ayrıca bu tür alanların yakın çevrede olduğunun ve gerektiğinde ulaşılabileceğinin bilinmesinin bile psikolojik olarak olumlu bir etkisi bulunmaktadır (Özgüner, 2004: 98). Bu araştırmalar yapma çevrede doğal çevre unsurlarına sahip olmanın önemini kanıtlar niteliktedir. Kellert (2005: 10), doğal çevrenin, modern kent toplumunda bile insanın tamamlanabilmesi için vazgeçilmez ve yeri doldurulamaz temel bir kaynak olduğunu belirtmektedir. Ancak insanların yaşamakta olduğu yapma çevrenin doğal çevre ile etkileşimindeki yetersizliği, yapma çevrenin tasarımı ve geliştirilmesinde yenilikçi bir yaklaşım ile çözülebilir. Yapma çevre oluşturulurken insanlarla doğal çevre arasında yeterli ve tatmin edici bir etkileşimi sağlamak üzere tasarımlar yapılması gerekmektedir. 
Doğal çevre ile etkileşimin insanlarda stresi azalttığı bilinmektedir fakat bu etkileşimi günümüzde sağlamak oldukça zordur. İnsan hayatının büyük bölümünü geçirdiği iç mekânlarda ise bu etkileşimi sağlamanın en yaygın yolu iç mekân bitkileridir. Ancak iç mekân bitkileri dış mekândaki eşdeğerlerinden çok daha az faydalıdır. Nute ve Weiss (2016: 41), iç mekân bitkilerinin daha etkisiz olma durumunu dış mekân bitkilerinin sahip olduğu karakterize özellik olan görünür hareketten yoksun olmaları durumundan kaynaklandığı görüşüne dayandırmaktadır.

Elde edilen veriler insanların yaşam alanlarında doğal çevre ile etkileşim kurma olanaklarının gittikçe zorlaşacağını göstermektedir. Bunun sebeplerinden biri de hızlı ve çarpık kentleşmedir. Kentleşme ile kronik hastalıkların artışları arasında bağlantı kurulmuştur. Öyle ki şehirlerde yaşamak, kalp hastalığı, kanser, diyabet felci, önlenebilir yaralanmalar ve akıl hastalığının kötüleşmesi gibi önde gelen morbidite ${ }^{2}$ ve mortalite $^{3}$ nedenleri için risk faktörü haline gelmiştir (McNally, 2014: 14). Yapma çevrenin aksine doğal çevre ile kurulan etkileşim ise insanların fizyolojik ve psikolojik sağlıklarına olumlu yönde katkılar sağlamaktadır. Ulrich'in (1984: 420,421), PennsyIvania Hastanesi'nde safra kesesi ameliyatı olan hastalar üzerinde yapmış olduğu çalışma, ağaçlara bakan odalarda kalan hastaların tuğla duvara bakan odalarda kalan hastalara oranla daha kısa süre hastanede kaldıklarını göstermektedir. Araştırma sürecinde hastalar ile ilgilenen hemşirelerin pozitif ve negatif olmak üzere almış oldukları notlara göre doğal çevreye bakan odalarda kalan hastaların daha pozitif yorumlar almış olduğu ve ağrı kesici ilaçlara daha az intiyaç duydukları görülmüştür.

Doğal çevre ile etkileşim kurmanın stresi azaltma ve iyileşme gibi fizyolojik etkilerinin yanı sıra dikkat, odaklama ve öğrenme unsurlarını geliştirdiğini gösteren çalışmalar da mevcuttur. Ağaçları görmek ve tercih edilen manzaraya sahip olmak, rahat ve huzurlu olma duygusu için önemlidir. Görüş alanlarında daha çok doğal çevre unsuruna sahip olan insanlar unutkan ve düzensiz olma durumlarını daha az muhtemel olarak değerlendirmişlerdir. Ağaçlar, çiftlik arazisi veya tarlaları görebilmek, daha az dikkati dağılmış hissetmeye katkıda bulunmaktadır. Ayrıca bitki örtüsü ve özellikle su unsuruna sahip manzaralar, kentsel manzaralara oranla ilginin sürmesini ve dikkatin güçlenmesini sağlamaktadır (Kaplan, 2001: 527). Berman, Kross, Krpan, Askren, Burson, Deldin, Kaplan, Sherdell, Gotlib veJonides (2012: 301), yapmış oldukları çalışmada dikkat, odaklanma ve öğrenme kapasitesinin doğal çevre unsurları ile etkileşim kurulduğunda arttığını göstermektedir. Bu çalışmada katılımcılar, bir botanik bahçesi olan AnnArborAr-

2 Morbidite hastalık, hastalık hali, hasta olma oranı anlamına gelmektedir.

${ }_{3}^{3}$ Mortalite ölüm, ölüm oranı olarak tanımlanmaktadır. boretum'una veya AnnArbor şehir merkezine 50-55 dakikalık bir yürüyüşe çıkmışlardır. Botanik bahçesi yürüyüşü ağaçlarla kaplı, trafikten ve insanlardan uzak bir güzergâha sahip iken, şehir merkezi yürüyüšü büyük oranda üniversite ve ofis binalarının sıralandığı, trafiğin yoğun olduğu bir caddede yapılmıştır. Yürüyüşten sonra katılımcılar laboratuvara dönmüşler ve sayı uzamı testini yapmışlardır. Bir hafta sonra, katılımcılar yürüyüş yerlerini karşılıklı değiştirerek prosedürü tekrarlamışlardır. Yapılan çalışma ile katılımcıların doğada yürüdüklerinde sayı uzamı testindeki performanslarının önemli ölçüde geliştĭgi, ancak şehir merkezinde yürüdüklerinde gelişmediği sonucuna ulaşılmıştır.

1950'lerde Donald Hebb'in Uyarılma Teorisi, insanların dikkatli kalmaları için bir miktar değişen duyu uyarısına intiyaç duyduklarını ortaya koymuştur. Değiş̧meyen ortamların dikkatli kalma durumunda hızlı bir düşüşe yol açtığını ve uyarıcı olmayan koşullarda konsantrasyonu sürdürmeye çalıştığımızda yorgunluğa ve strese neden olduğunu iddia etmektedir. Hebb'den kırk yıl sonra, Rachel ve Stephen Kaplan tarafından geliştirilen Dikkat Restorasyon Teorisi, doğal çevreye ait birçok unsurun bilinçli çaba gerektirmeden duyuları teşvik ederek stresi rahatlatıyor olduğunu ortaya koymuştur (Nute ve Weiss, 2016: 42). Evrimsel psikoloji ise hem doğal çevreye hem de algılanabilir değişime olan ihtiyacımızı, insan fizyolojisinin sürekli değişen doğal dünyaya cevaben büyük ölçüde dışarıda evrimleştiği gerçeğine bağlamaktadır. On beş nesil önce atalarımız, evrimsel açıdan çok az sonuç veren bir süredir, uyanık oldukları saatlerinin çoğunu dışarıda geçirmekte idi.

Yapılan araştırmalar da göstermektedir ki insanın sağlıklı bir şekilde hayatını sürdürmesi için doğal çevre ile uyum içinde yaşaması gerektedir.Yapma çevre oluşturma insan yaşamı için kaçınılmazdır ancak bunu doğaya zarar vermeden sürdürülebilir şekilde yönetmek ve gerçekleştirmek gerekmektedir. Sürdürülebilir tasarım konusunda önde gelen yorumcular ve özellikle de son zamanlarda Kellert (2005: 10), mimarlı̆ıın artık sadece korumak veya zarar vermemek üzerine yapılmasının yeterli olmadı̆̆ını savunmaktadır. Aksine şu anda karşılaştığımız göz korkutucu çevresel problemler üzerinde anlamlı bir etki yaratabilmek için binaların doğal çevre ile uyum içinde yaşamanın bariz yollarını göstermesi gerektiği konusunda ısrar etmektedir.

\section{Alan Çalışması}

İç mekânda doğal çevre unsurları ile etkileşim halinde olmanın kullanıııların psikolojik iyi oluş durumlarını olumlu yönde etkilediği hipotezini test etmek üzere bir deney grubu oluşturulmuştur. Deney grubu ile doğal çevre, yapma çevre ve hem doğal çevre hem de yapma çevre unsurlarının bir 
arada olduğu üç farklı sınıfta alan çalışması gerçekleştirilerek bu unsurların kullanıcıların mentâl iyi oluş durumları üstündeki etkisi değerlendirilmiştir.

Katılımcılar iç mimarlık bölümü birinci sınıf öğrencilerinden oluşmaktadır. Çalışmalarında dikkat unsurunun önemli bir etken olduğu iç mimarlık gibi uygulamalı bir alanda bir takım yöntem ve tekniklerin yeni kazanıldığı birinci sınıf grubunda, bulundukları sınıfın doğal çevre unsurlarına sahip olup olmamasının mental iyi oluş durumunda hissedilebilir bir fark yaratacağ düşünülmüştür.

Deney grubu ile üç aşamalı olarak; doğal çevre unsurlarından deniz ve gökyüzünü gören sınıfta, sadece yapma çevre unsurlarını gören sınıfta ve son olarak da doğal çevre ve yapma çevre unsurlarını bir arada gören sınıfta serbest el perspektif çalışması gerçekleştirilmiştir. Yapılan perspektif çizimleri değerlendirme ölçütü olarak kullanılmamıştır. Yapılan her çalışmanın sonunda 14 sorudan oluşmakta olan ve bireyin mentâl iyi oluş durumunu ölçmek için kullanılan Mentâl İyi Oluş Ölçeği deney grubu tarafından cevaplandırılmışıır. Dünya Sağlık Örgütü mentâl iyi oluşu bireyin yeteneklerinin farkında olması, stresin üstünden gelebiliyor olması, üretken ve faydalı olarak yetenekleri doğrultusunda topluma katk sağlıyor olması olarak tanımlamaktadır (Keldal, 2015: 104).Türkçeye uyarlaması "Warwick-Edinburgh Mental İyi Oluş Ölçeği'nin Türkçe Formu: Geçerlik ve Güvenirlik Çalışması" ile gerçekleştirilen bu ölçek 14 maddeden oluşmaktadır. Ölçekte alınan yüksek puanlar yüksek mentâl iyi olus durumunu gösterirken, en düşük 14 puan, en yüksek 70 puan alınabilmektedir (Keldal, 2015: 105). Geçerlik ve güvenirlik çalışması yapılan ölçeğin pozitif psikoloji alanında konuyla ilgili önemli bir eksikliği gidereceğini belirten Keldal (2015: 111), ayrıca bireylerin mentâl iyi oluş düzeylerini etkileyecek nedenlerin daha kolay değerlendirilebileceğini belirtmektedir.

Katılımcılara her çalışma sonrasında verilen Mentâl İyi Oluş Ölçeği ile yapılan kurgunun detayları, sonuçları etkilememek adına üç çalışma da tamamlandıktan sonra açıklanmıştır. Bunun nedeni doğrudan bir yönlendirmeye neden olma ihtimalini önlemektir. Çalışmaya örneklemin yüzde 40'ının katııımı gerçekleșmiş ve 20 kișilik bir çalıșma grubu oluşturulmuştur. Katılımcı yaş ortalaması erkeklerde 19, kadınlarda ise $18,8^{\prime}$ dir. Grubun ortalama yaşı ise $18,9^{\prime}$ dur.

Mimar Sinan Güzel Sanatlar Üniversitesi Fındıkı Kampüsü Mimarlık Fakültesine ait üç sınıf çalışma mekânı olarak kullanılmıştır. Yapının yerleşimi mekân seçiminde büyük bir öneme sahiptir (Şekil 2). Hem doğal çevre unsurlarını hem de yapma çevre unsurlarını gören sınıfları mevcut olan yapının, ayrıca sadece binanın içinde kalan ve dış çevre ile etkileşimi olmayan sınıfları da mevcuttur. Mekânın bu avantajı sayesinde doğal çevre, sadece yapma çevre ve son olarak da doğal çevre ile yapma çevre unsurlarını aynı anda gören sınıflarda çalışmalar gerçekleştirilmiştir.

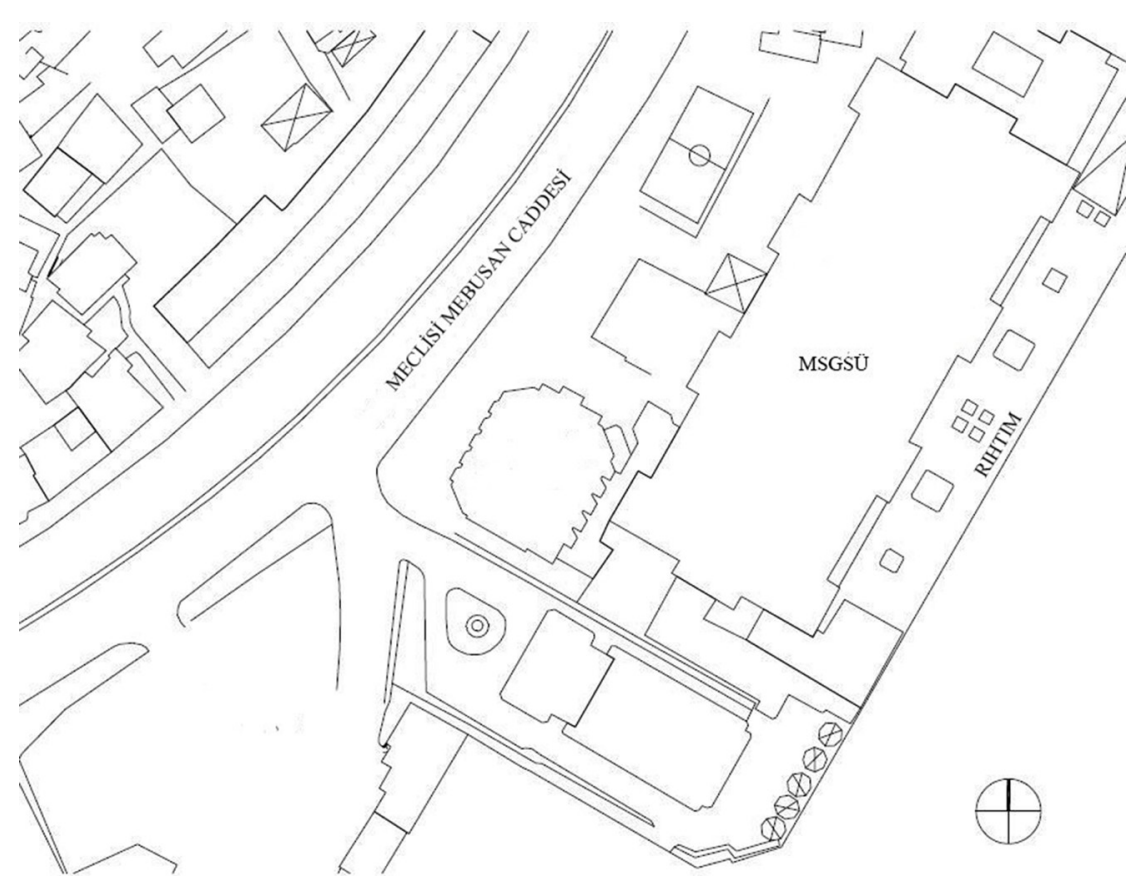

Şekil 2. MSGSÜ Vaziyet Planı (Kurtulan, 2009)

Şekil 3'te ilk çalışmanın gerçekleştirildiği doğal çevre unsurlarını gören sınıfın plan çiziminde bulunduğu alan renklendirilmiş ve 1 rakamı ile gösterilmiştir. Bu sınıf binanın birinci katında bulunmaktadır.

DENIZ YÖNÜ

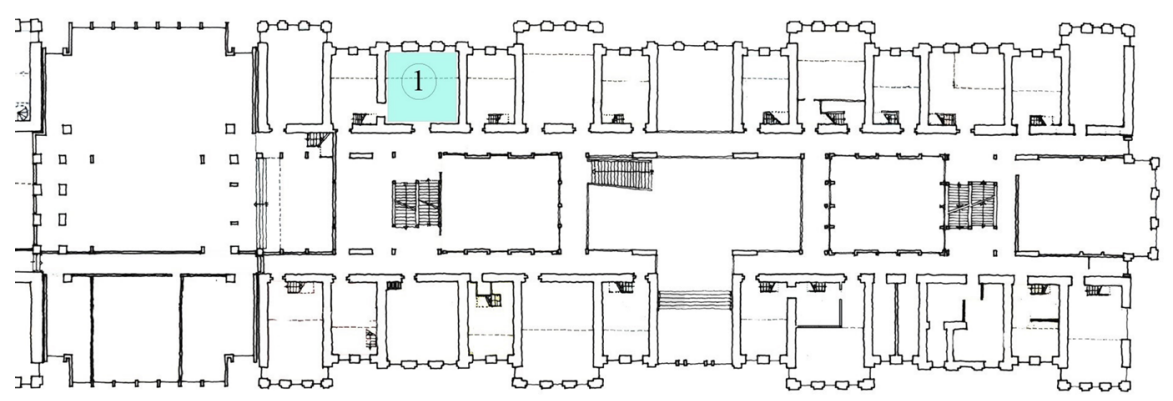

Şekil 3. IIlk çalışmanı gerçekleştirildiği sınıf 
Sınıfın pencereleri binanın rıhtım yönüne, doğrudan denize bakmaktadır (Şekil 4). Bu sınıfta yapılan çalışma ile doğal çevre unsurlarından güneş ışı̆ının yanı sıra denizi ve gökyüzünü görüyor olmanın katılımcıların mentâl iyi oluş durumları üzerindeki etkileri değerlendirilmiştir.
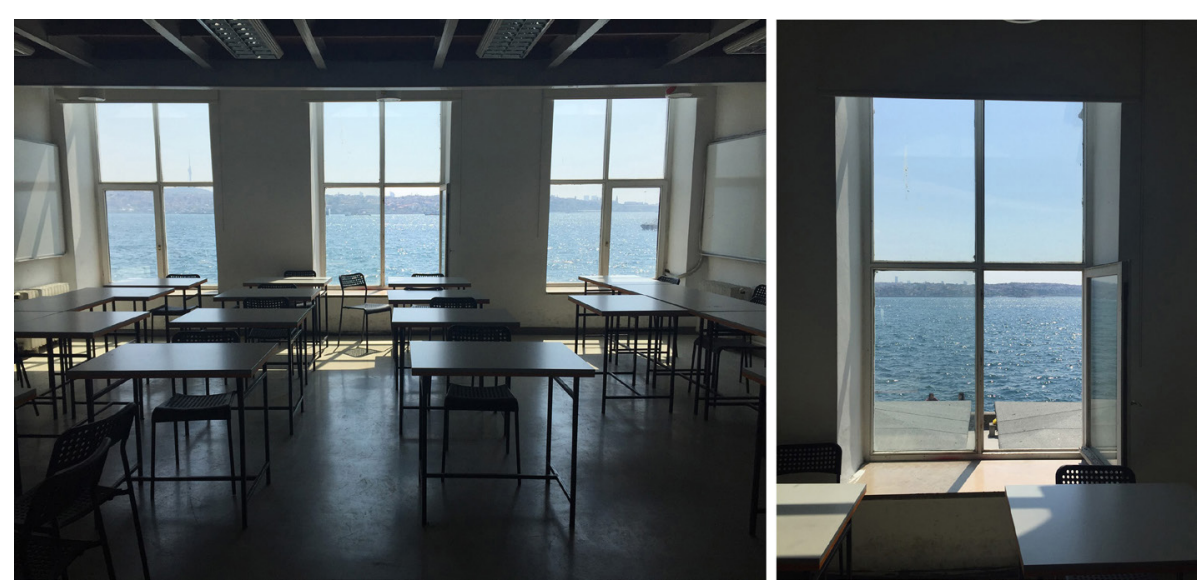

Şekil 4. Birinci çalışmanın yapıldığı sınıf (Aşkın,2019)

Çalışmanın ikinci ve üçüncü aşamasının gerçekleştirildiği sınıflar şekil 5 'te gösterilmiş̧ir. Planda ikinci çalışmanın gerçekleştirildiği sınıf kırmızı ile renklendirilmiş ve 2 rakamı ile gösterilmiştir. Üçüncü çalışmanın gerçekleştirildiği sınıf ise yeşil ile renklendirilmiş ve 3 rakamı ile gösterilmiştir. Bu sınıflar binanın ikinci katında bulunmaktadır.

Calıșmanın ikinci aşaması binanın dıs çevresi veva doğal çevre ile etkileșimi

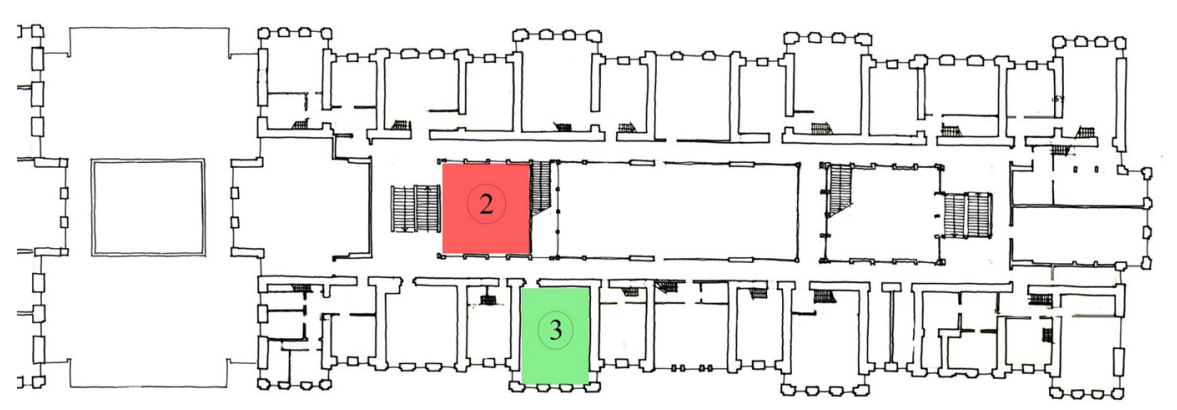

Şekil 5. íkinci ve üçüncü çalışmaların gerçekleştirildiği sınıflar. olmayan, sadece yapma çevresi bulunan bir sınıfta gerçekleştirilmiştir (Şekil 6). Sınıfın pencereleri koridor ve merdivene bakmaktadır.
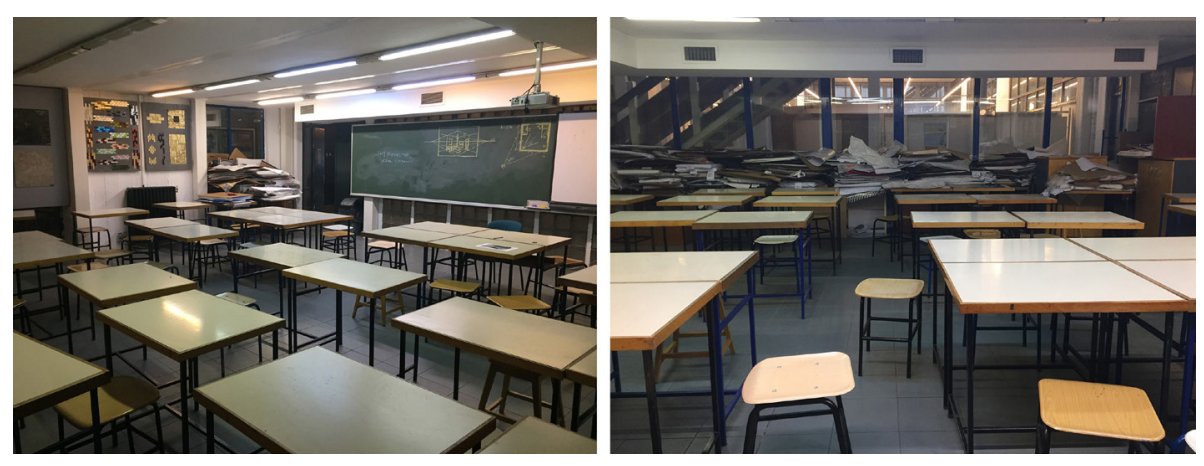

Şekil 6. Ikinci çalışmanın yapıldığı sınıf (Aşkın,2019)

Üçüncü çalışmanın gerçekleştirildiği sınıf yapma çevre unsurlarından binalar, cadde, basketbol sahası ve doğal çevre unsurlarından ağaçları aynı anda görmektedir (Şekil 7). Bu sınıfta gerçekleştirilen çalışma ile doğal çevre ve yapma çevrenin bir arada olmasınınmentâl iyi oluş durumuna olan etkileri değerlendirilmiştir.
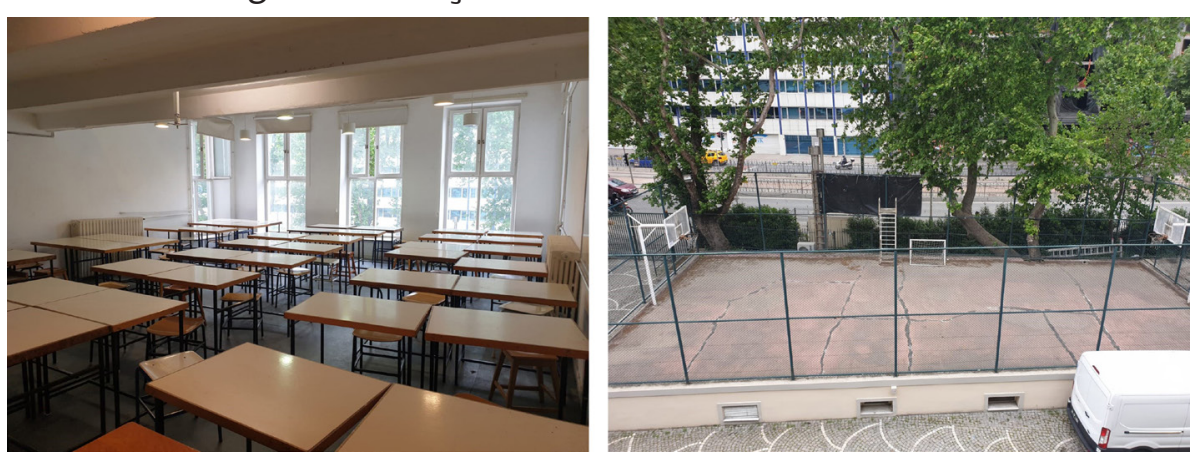

Şekil 7. Üçüncü çalışmanın yapıldı̆̆ı sınıf ve pencereden görülen alan (Aşkın,2019)

\subsection{Bulgular, Değerlendirme ve Tartışma}

Bu çalışmanın sonuçları değerlendirilirken katııımcının almış olduğu puan, ölçek sonucunda alınabilecek en yüksek puan olan 70'e bölünüp, 100 ile çarpılarak 100 üzerinden bir değerlendirme yapılmıştır.

Birinci çalışma doğal çevre unsurlarından güneş ışı̆̆ı, deniz ve gökyüzünü 
gören sınıfta, ikinci çalışma sadece yapma çevreye sahip olan sınıfta, üçüncü çalışma ise hem doğal çevre hem de yapma çevre unsurları ile etkileşimi olan sınıfta yapılmıştır. Bu çalışmaların sonunda katılımcıların almış olduğu mentâl iyi oluş ortalamaları Şekil 8'de sunulmuştur.

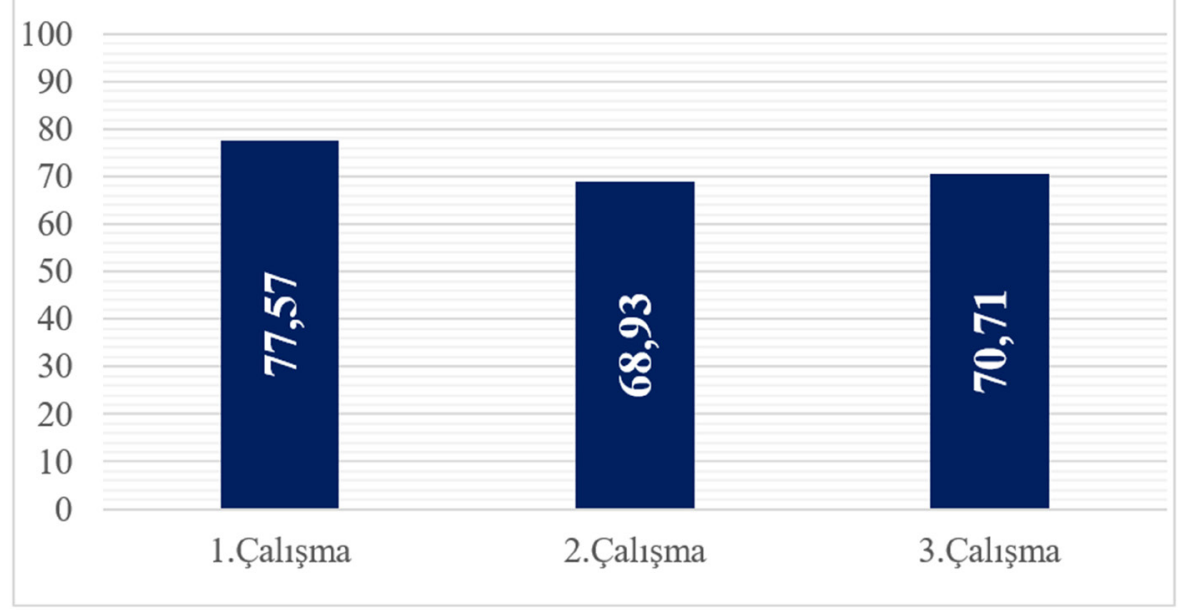

Şekil 8. Yapılan 3 çalışmada deney grubunun ortalama mentâl iyi oluş puanları

Ölçek sonuçlarına göre üç çalışma arasında katılımcıların mentâl iyi oluş durumları en yüksek deniz unsuruna sahip olan sınıfta yapılan çalışma sonucunda alınmıştır. Bunu hem doğal çevre hem de yapma çevre unsurlarına sahip olan sınıfta yapılan çalışma izlerken, en düşük mentâl iyi olus sonuçları sadece yapma çevre unsurlarını gören ikinci çalışma sonunda alınmıştır. Deniz gören sınıfta yapılan çalışmanın ardından gerçekleştirilen ölçekten alınan puan diğer iki çalışmadan sonra yapılan ölçek sonuçlarından çok daha yüksek iken, ikinci ve üçüncü çalışmanın sonuçları arasında küçük bir fark çıkmıştır. Ancak hem doğal çevrenin hem de yapma çevrenin göründüğü sınıfta yapılan çalışmanın sonucu, sadece yapma çevreye sahip olan sınıfta yapılan ölçek sonucundan yüksektir. Bu çalışmanın verilerine göre doğal çevre unsurlarının, özellikle deniz unsurunun mentâl iyi oluş durumunda önemli bir etkisi olduğu sonucuna ulaşılmaktadır.

Yapılan üç çalışma sonucunda elde edilen mental iyi oluş sonuçlarının cinsiyete göre ortalamaları Şekil 9'da verilmiştir. Erkek katılımcıların ortalama mentâl iyi oluş puanları kadın katılımcılara kıyasla her üç çalışmada da daha yüksek çıkmıştır.

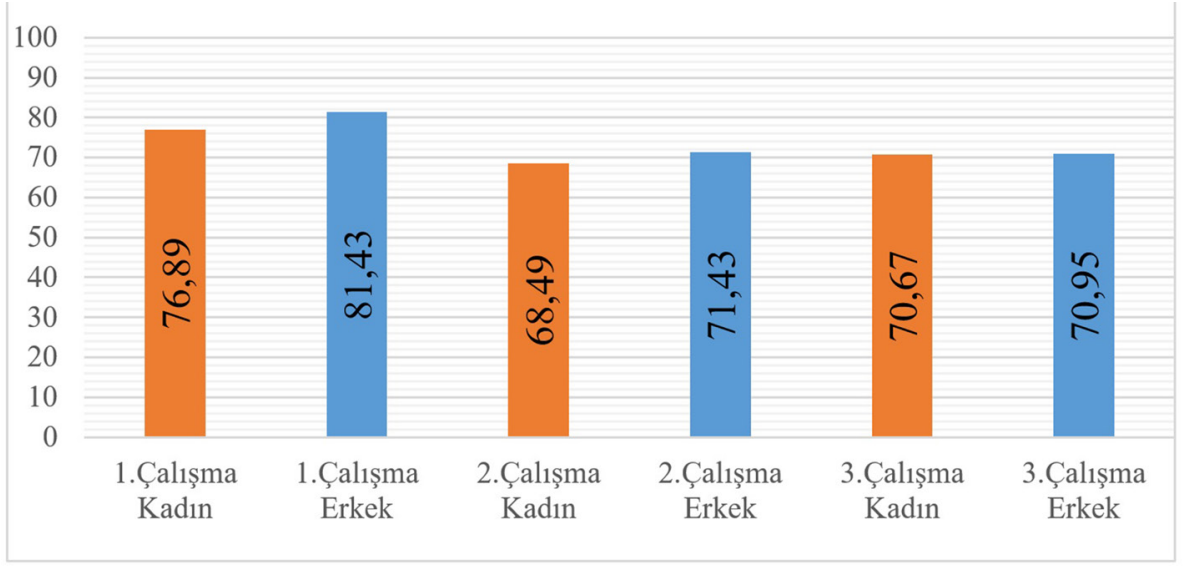

Şekil 9. Cinsiyete göre ortalama mentâl iyi oluş puanları

Doğal çevre unsurlarından denizi gören sınıfta yapılan birinci çalışmada mentâl iyi oluşu en yüksek olan 3 katılımcının puanları Şekil 10'da, en düşük olan 3 katılımcının puanları ise Şekil 11'de gösterilmiştir.

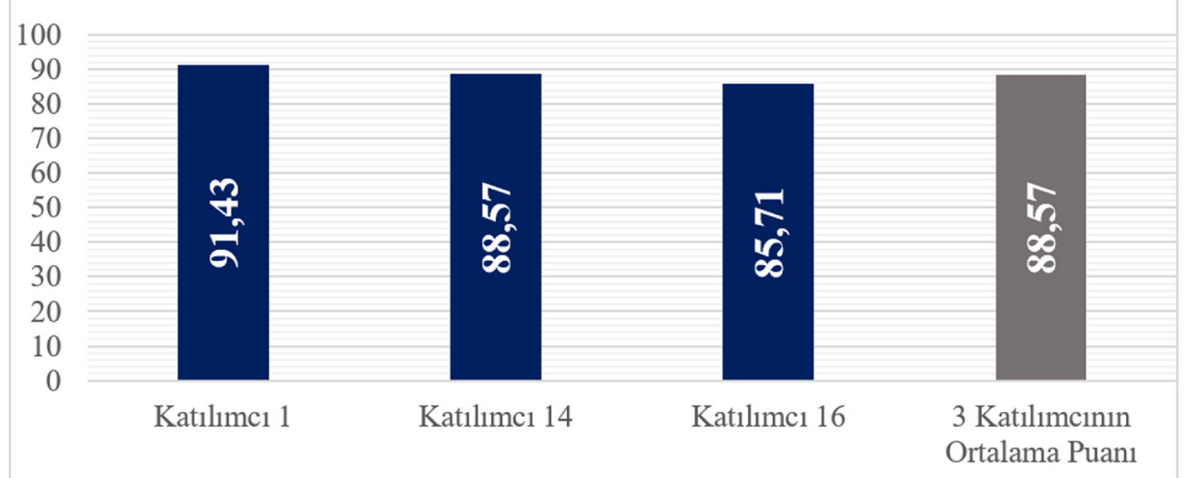

Şekil IO. Birinci çalışmada mentâl iyi oluşu en yüksek olan 3 katılımcının puanları

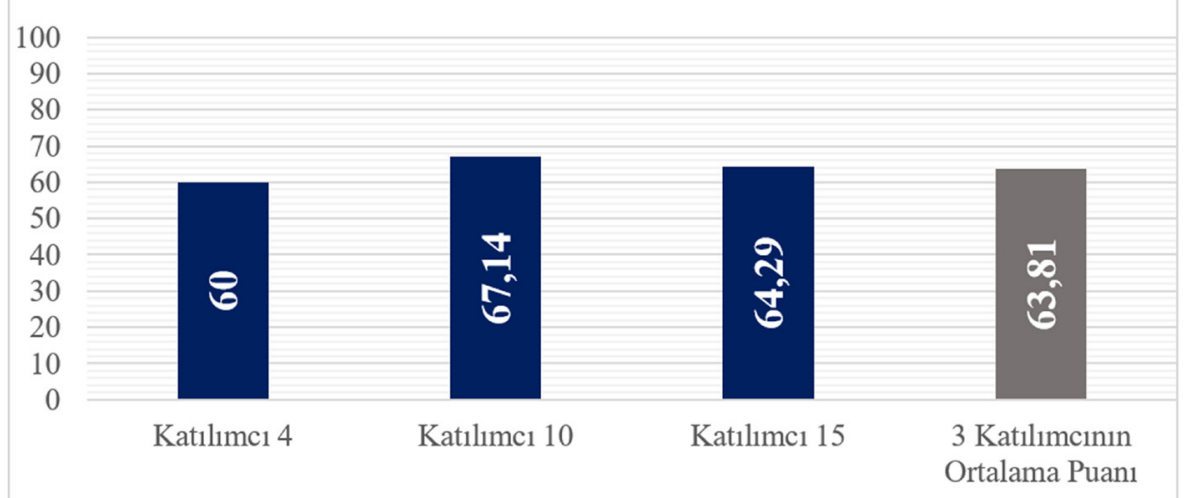

Şekil II. Birinci çalışmada mentâl iyi oluşu en düşük olan 3 katılımcının puanları. 
Çalışmanın sadece yapma çevre unsurlarına sahip olan sınıfta yapılan ikinci aşamasında mentâl iyi oluşu en yüksek olan 3 katılımcının puanları Şekil 12 'de, en düşük olan 3 katılımcının puanları ise Şekil 13'te gösterilmiştir.

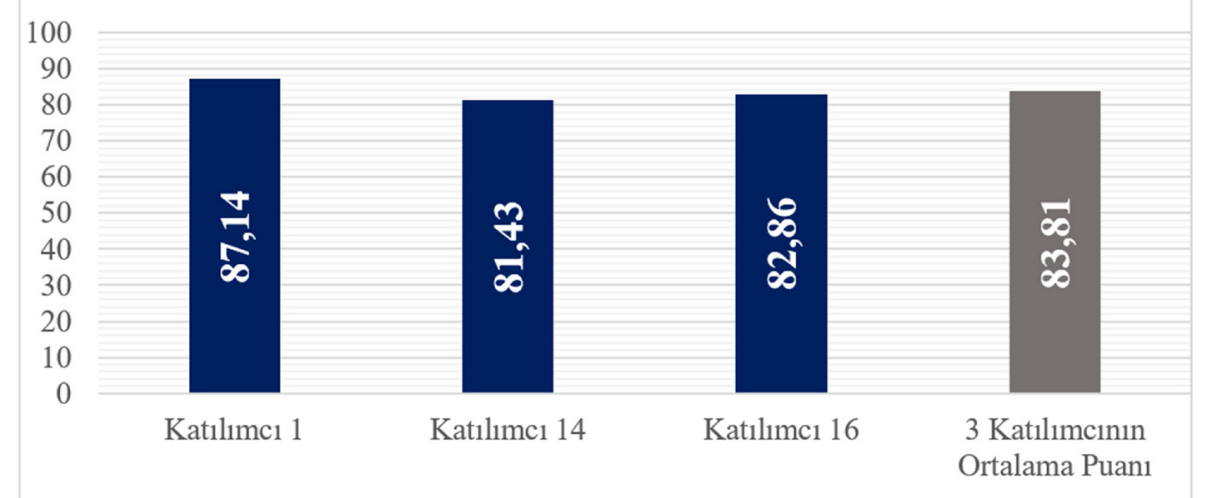

Şekil I2. Ikinci çalışmada mentâl iyi oluşu en yüksek olan 3 katılımıının puanları

İinci çalışmada en yüksek mentâl iyi oluş puanına sahip olan katılımcılar birinci çalışmada da en yüksek puana sahip olan 1, 14 ve 16 numaralı katılımcılar olmuştur. Ancak ikinci çalışmada bu katıımcıların mentâl iyi oluş puanları daha düşük çıkmışıır.

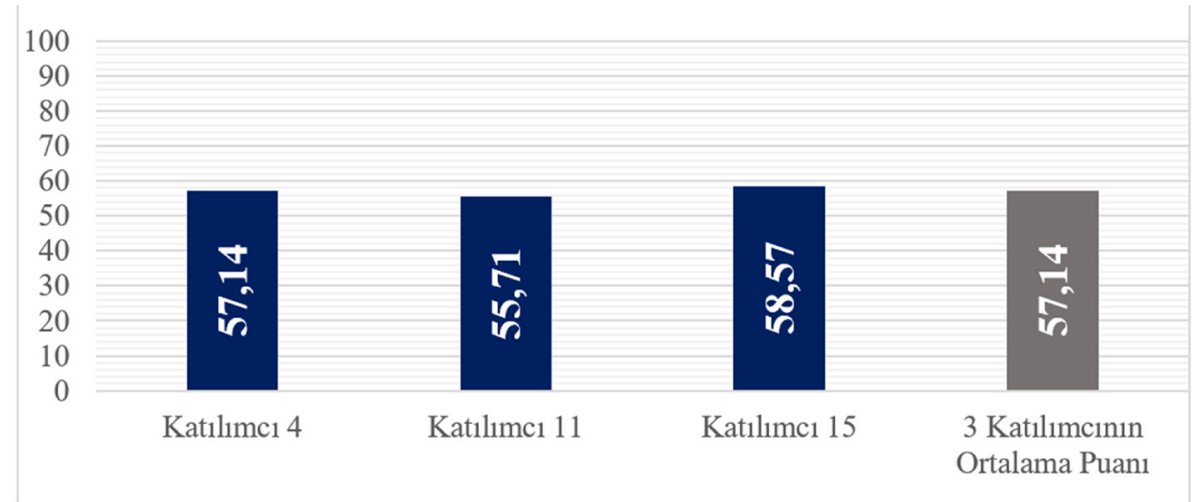

Şekil I3. Ikinci çalışmada mentâl iyi oluşu en düşük olan 3 katılımcının puanları

Hem en yüksek mentâl iyi oluş puanına sahip olan katılımcıların hem de en düşük puana sahip olan katılımcıların puanlarının ikinci çalışmada düşmüş olması, doğal çevre unsurları ile etkileşim kuruyor olmanın mentâl iyi oluş durumu üzerinde sadece yapma çevre unsurlarıly etkileşim kurulması ile karşılaştırıldığında pozitif bir etkiye sahip olduğunu göstermektedir. Bu fark özellikle deniz unsuruolduğu zaman daha fark edilir duruma gelmektedir.

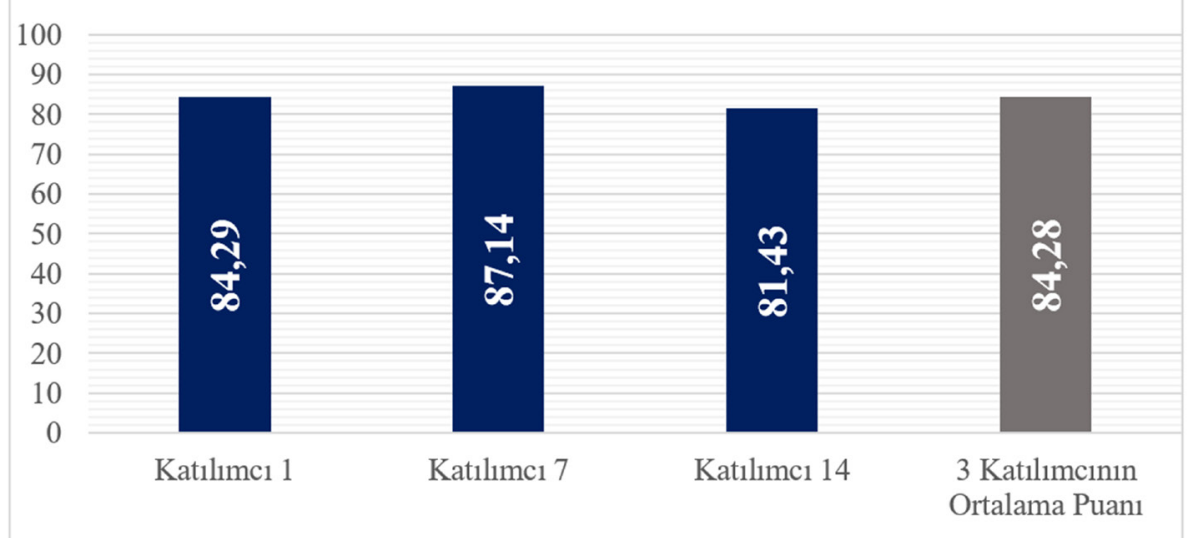

Şekil I4. Üçüncü çalışmada mentâl iyi oluşu en yüksek olan 3 katılımcının puanları

Çalışmanın hem doğal çevre, hem de yapma çevre unsurlarını gören sınıfta yapılan aşamasında mentâl iyi oluş durumu en yüksek olan 3 katılımcının puanları Şekil 14'te, en düşük olan 3 katılımcının puanları ise Şekil 15 'te gösterilmiştir.

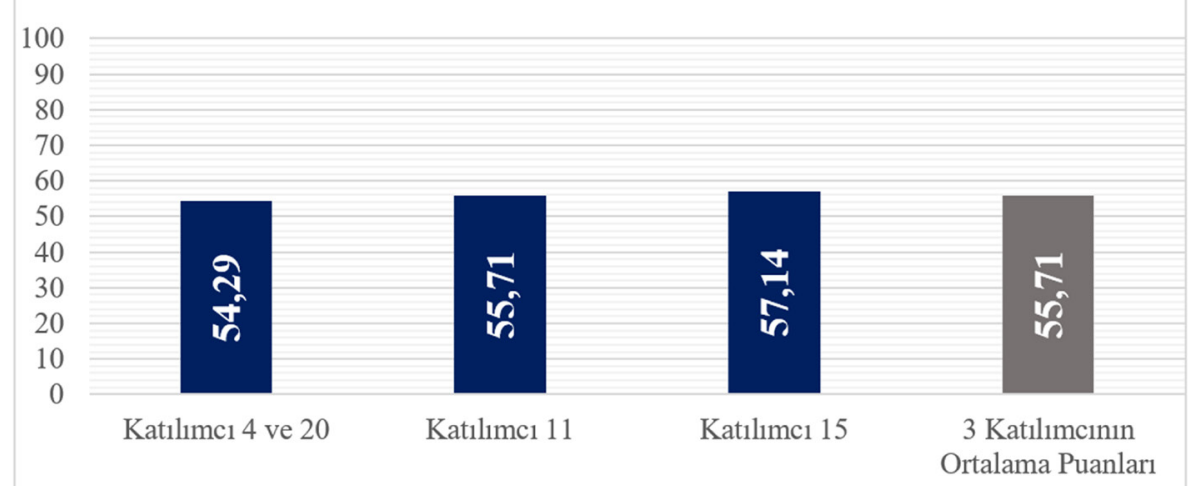

Şekil 15. Uçüncü çalışmada mentâl iyi oluşu en düşük olan 3 katııımcının puanlar

Katılımcı 1 ve 14 ilk iki çalışmada olduğu gibi bu çalışmada da en yüksek puanı alan katılımcılar olmuşlardır. Katılımcı 1 üççalışma arasından 84,29 ile en düš̈u puanını bu çalışmada almıștır. Katııımcı 14 ise üçüncü çalıșmada 81,43 alarak ikinci çalışmada almış olduğu puanla aynı puanı almıştır. Ancak birinci çalışmaya göre puanı düşmüştür. 
4 numaralı katılımcı birinci ve ikinci çalışmada da en düşük mentâl iyi oluş puanına sahiptir. Ancak bu üç çalışma arasında en düşük puanı bu çalışmada almıştır. Katılımcı 11 ise 55,71 puan almıştır. Bu katılımcı ikinci çalışmada da aynı sonucu almıştır. Katılımcı 15 ise bu çalışmada 57,14 puan almıştır. Diğer iki çalışmada da en düşük mentâl iyi oluş puanı alan kişilerden olan katıımcı 15'in bu çalışmada aldığı puan kendi içinde değerlendirildiğinde almış olduğu puanlar içinde en düşük puanıdır.

Doğal çevre ve mentâl iyi oluş durumu arasındaki pozitif ilişki bu çalışma ile gösterilmektedir. Doğal çevre unsurlarına sahip olan sınıfta yapılan çalışma sonrasında katılımcıların almış olduğu mentâl iyi oluş puanlarının yüksek çıkmış olması bu durumu kanıtlamaktadır. Yapma çevre unsurlarını gören sınıfta yapılan çalışma sonrasında alınan mentâl iyi oluş ölçeği sonuçları ile hem doğal çevre hem de yapma çevre unsurlarını gören sınıfta yapılan çalışma sonrasında alınan sonuçlar arasında küçük bir farka ulaşılmıştır. Ancak üç çalışma arasında en düşük mentâl iyi oluş puanları, sadece yapma çevre unsurlarına sahip olan sınıfta yapılan çalışma sonrasında alınmıştır. Sonuçlar iç mekânda doğal çevre unsurları ile etkileşim kurmak gerektiği fikrini desteklemektedir.

Mentâl iyi oluş ölçeğinin sonuçlarının değerlendirilmesinde 20 katılımcıya ait genel grafiklerin yanı sıra üç çalışma için de mentâl iyi oluş durumu en yüksek ve en düşük olan 3 katılımcıya ait grafiklere de yer verilmiştir. Bu grafikler bireysel değerlendirmede de iç mekânda doğal çevre unsurları ile etkileşim halinde olmanın, mentâl iyi oluş durumu üstünde olumlu bir etki yarattığını göstermektedir.

\section{Sonuç ve Öneriler}

Bu çalışma kapsamında yapılan deney kurgusu ile iç mekânda doğal çevre ile etkileşim kurulmasınınmentâl iyi oluş durumu üstünde pozitif etkisi olduğu görülmüştür. Bu çalışmanın konusu insan ve yapı sürecini kapsayan birçok disiplin için önemlidir. İnsanın doğal çevre üzerindeki tahribatı devam ettikçe de önemini sürdürmeye devam edecektir. İnsan hayatının büyük bir oranının iç mekânlarda geçtiği düşünüldüğünde iç mekânlarda doğal çevre ile etkileşim kuruyor olmak da önemli olmaya devam edecek ve çözülmesi gereken bir durum olarak var olacaktır.

Günümüzde birçok mekânda doğal çevre ile etkileşim tasarımda ön planda olan bir unsur değildir ve yapılar bu etkileşimi sağlamakta yetersiz kalmaktadır. Bu durumun değişmesi için yapma çevre oluşturma sürecine dâhi olan bütün disiplinlerin doğal çevre ve insan arasındaki bağların koparılmaması gerektiğini kavraması gerekmektedir. Yapma çevrenin tasarımı ve geliştirilmesinde doğal çevre ile etkileşimi sağlamaya yönelik bir yaklaşım benimsenerek hareket edilmesi gerekmektedir.

Doğal çevre unsurları olmadan tasarlanmış bir çevre var oldukça iç mekân ile çevre arasında etkileşimi sağlayan en önemli araçlardan biri olan pencereler bu etkileşimi sağlamakta yetersiz kalacaktır. Bu nedenle öncelikle yapma çevre oluşturulurken yapının çevresinin doğal çevre unsurlarını da barındırmasına dikkat edilmeli ve kullanıcılar iç mekânda iken de bu unsurlar ile etkileşim kurabilecekleri şekilde tasarlanmalıdır.

Çoğu kullanıcı pencereye sahip olan mekânlarda yaşamayı tercih etmektedir. Ancak her mekân pencereye sahip değildir. Bu tip mekânlarda iç mekân bitkilendirme, iç avlu, bahçe ve su unsuru gibi çeşitlendirebileceğimiz doğal çevreye ait iç mekânda kullanılabilecek ögeleri tasarım yoluyla içeriye almak, doğal çevre ve kullanıcı etkileşimini sağlamakta yardımcı olacaktır.

Özellikle şehirler doğal çevre unsurları bakımından çoğunlukla yetersizdir. Doğal çevreye ulaşmanın zor olduğu bu durumlarda güneş ışığı, yağmur, su, rüzgâr gibi gözden kaçırdığımız doğal çevre unsurlarını tasarım yoluyla iç mekânlara dâhil etmek, doğal çevreden yoksun olan ortamlarda bu etkileşimin kurulması için kullanılabilecek bir yöntem olacaktır.

Doğal çevre ve insan etkileşimi ile ilgili tasarımcılar kadar kullanıcılar da bilinçlendirilmelidir. İnsan doğal çevrenin bir parçasıdır ancak zamanla oluşturduğu yapma çevre ile ondan uzaklaştırmıştır. Bir parçası olduğu doğa çevre unsurları ile etkileşim halinde olması gerektiği gerçeğini kavramalıdır.

Bu çalışmanın ortaya koymuş olduğu bulguların desteklenmesi için daha kapsamlı örneklemler üzerinden devam çalışmaları yapılması konunun öneminin anlaşılması ve bu etkileşimin yapma çevre oluşturulurken dikkat edilmesi gereken ve birçok disiplini ilgilendiren bir unsur olduğu bilgisini pekiştirmek adına önemlidir. 


\section{Kaynakça}

Atasoy, E. (20I5). İnsan-Doğa Etkileşimi ve Çevre İçin Eğitim. İstanbul: Sentez Yayıncilık.

Berman M.G. Kross E. Krpan K. M. Askren M. K. Burson A. Deldin P. J. Kaplan S. Sherdell L. Gotlib I. H. ve Jonides J. (20I2). “InteractingWith Nature ImprovesCognitionandAffectForIndividualsWithDepression”, Journal of AffectiveDisorders 140, s. 300-305.

Harari, Y.N.(20I5). Hayvanlardan Tanrılara Sapiens. İstanbul: Kolektif Kitap.

Hun, E. (2016). Tarih Boyunca Insan-Çevre İlişkisi. Ruşen Keleş (Yayına Hazırlayan). Insan Çevre Toplum. 3.Baskı. Ankara. İmge Kitabevi Yayınları, s.50

Kaplan, R. (200I).“The Nature of The View From Home, Environment and Behavior", Vol. 33 No. 4, July, S. 507-542.

Karataş, A. (20I3). “Gençlerin Doğal Çevre ile Etkileşim Kurmalarının Güvenli Yarınlar Icin Önemi”, Düşünce Dünyasında Türkiz Siyaset ve Kültür Dergisi Yıl:4 / Sayı: 23 / Eylül - Ekim.

Keldal, G. (20I5). “Warwick-Edinburgh Mental lyi Oluş Ölçeği'nin Türkçe Formu: Geçerlik ve Güvenirlik Çalışması”, Thejournal of Happiness\&Well-Being, 3(I), s. I03-

Keleş, R. Hamamcı, C. (2005). Çevre Politikası. Ankara: İmge Kitabevi.

Kellert, S.R. (2005).“'BuildingFor Life:DesigningandUnderstandingThe Human-Nature Connection”, RenewableResourcesjournal.

Mcnally, W. (20I4). "Planning For Small \& Ordinary Natural Urban Spaces To Enhance MentalHealth \& Well-Being: The Psychological Health Benefits From Contact With Nature”. Yüksek Lisans Tezi, University of Washington, Washington.

Monnier, G. (20I3).Mimarlık Tarihi. Ankara: Dost Kitabevi Yayınları.

Nute, K. ve Weiss, A. (2016). “Outside In: Using The Animation Of The Weather To Improve Building Occupants' Well-Being And Raise Awareness of Passive Energy and Rainwater Saving", The International Journal of Architectonic, Spatial and Environmental Design Volume 10, Issue 4.

Özgüner, H. (2004). “Doğal Peyzajın İnsanların Psikolojik ve Fiziksel Sağlı̆ı Üzerine Etkileri”, Süleyman Demirel Üniversitesi Orman Fakültesi Dergisi, Seri: A, Sayı: 2, YIl: 2004, ISSN: I302-7085, Sayfa: 97-I07

Ponting, C. (2012). “Dünyanın Yeşil Tarihi Çevre ve Büyük Uygarlıkların Çöküşü”(Çev. Ayşe Başcı).Istanbul. Sabancı Üniversitesi. 3. Basım.

Roth, L. M. (20।4).Mimarlığın Öyküsü, Öğeleri, Tarihi ve Anlamı. İstanbul. Kabala
Yayıncılık.

Taşkın, A. (20I0). “Çevrenin Hukuksal Yönden Korunması”, Türkiye Adalet Akademis Dergisi (Taad), Nisan 2010, Sayı: I

Tıraş. H. (20I2). "Sürdürülebilir Kalkınma ve Cevre: Teorik Bir Inceleme”,

Kahramanmaras Sütçü İmam Üniversitesi İktisadi ve İdari Bilimler Fakültesi Dergisi, Cilt 2, Sayı 2, s. 57-73.

Turgut, N. (200I).Çevre Hukuku.Ankara. Savaş Yayınevi. 2. Baskı.

Ulrich, R.S. (1984).“View Through a Window May

InfluenceRecoveryFromSurgery”, Science, New Series, Volume 224, Issue 4647, s. 420421 .

\section{Görsel Kaynaklar}

Așkın, H.(20।9).iç Mekânda Kullanıcı ve Doğal Çevre Etkileşimini Artırmaya Yönelik Yaklaşımlar, Yüksek Lisans Tezi.

Kurtulan, Z.(2009).M.S.G.S.Ü. Sedad Hakkı Eldem Oditoryumunun Hacim Akustiği Açısından Incelenmesi ve Değerlendirilmesi, Yüksek lisans tezi.

Ponting, C. (20I2).Dünyanın Yeşil Tarihi Çevre ve Büyük Uygarlıkların Çöküşü, Sabancı Üniversitesi, 3. Basım. 47, 280

\section{Internet Kaynakları}

Internet-I: https://www.who.int/health-topics/urban-health/urban-health-gallery (Erişim Tarihi 06.06.2020) 